\title{
Resurrection Appearances of Jesus as After-Death Communication: Rejoinder to Gary Habermas
}

\author{
Ken R. Vincent, Ed.D. \\ Houston, TX
}

\begin{abstract}
Gary Habermas has chosen to respond to my paper on the resurrection of Jesus as an after-death communication using theological arguments that try to prove the resurrection of Jesus was somehow a religious event unique in all human history. I counter his assertions with data from religious/spiritual experience research and, to a lesser extent, liberal Christian scholars. I restate my conclusion that Paul's first-hand and verified second-hand accounts of the resurrection in I Corinthians 15 are comparable with modern after-death communications; the difference between Jesus and others is not one of kind but of degree. Over the past 150 years, religious experience researchers have successfully applied the tools of science and begun to unlock the mysteries of how humans experience God and afterlife.
\end{abstract}

KEY WORDS: resurrection, Jesus, after-death communication, visions

Gary Habermas was correct in stating that he and I agree that Jesus was raised from the dead and that there is a substantial amount of data from religious experience research that points to an afterlife (Habermas, 2012). He acknowledged that scholars before me have suggested that Jesus' post-resurrection appearances might be interpreted as a variation of after-death communications (ADCs), also known as post-death visions. Although he affirmed the similarities between Jesus' post-resurrection appearances and modern-day ADCs, he was adamant that they are not the same. I believe that Habermas' theological

Ken R. Vincent, Ed.D., is a writer and religious experience researcher who is retired from teaching psychology at Houston Community College. He has over 150 publications in the areas of psychology and religion. Correspondence regarding this article should be sent to Dr. Vincent at 1701 Hermann Dr. \#2503, Houston, TX 77004; e-mail: professorvincent@yahoo.com. 
roots prevented him from accepting anything but a resurrected Jesus with a physical body, returned to Earth in a supernatural miracle, unique among other holy figures or ordinary people. As I have maintained in previous writings, "Truly supernatural miracles such as Moses parting the water, Jesus walking on water, and Buddha levitating and gliding over the water are outside the experience of the modern world and yet to be demonstrated by science" (Vincent, 2007, p. 7), but religious experience is as common today as it was in ancient times.

Some time after the editor of this Journal submitted my article to Habermas for his review and he agreed to write a response, he and I spoke on the telephone at length (personal communication, July 12, 2012). I was pleasantly surprised to learn that he had some knowledge of the growing amount of data on transpersonal experiences being mined in the fields of social science and medicine. However, in his References, he cited only two religious experience researchers: Michael Perry and myself (Habermas, 2012).

My article was intentionally based on research into spiritually transformative experiences (mystical experiences, deathbed visions, near-death experiences, ADCs) as integral to the normal, healthy human life experience. Habermas (2012) faulted me for ignoring "historians, philosophers, and New Testament researchers" (p. 151) and chose to frame his arguments in theological terms. However, my paper dealt with the universality of religious experience across time and culture, and any reference to philosophy or theology was only tangential. For me, theology is basically an argument about a book-or, in the case of the vast Hindu scriptures, a set of books. In my view, spiritually transformative experience is the basis for all that is holy in scripture, and the validity of the Bible or any other sacred book rests on the religious experience(s) in it. I share the view of William James that religious experience is primary, and religion is secondary (James, 1902/1990, p. 35).

My doctorate is in counseling psychology, and I am a religious experience researcher; I use the older term "religious" because the topic of my original article is the resurrection. Many of my colleagues prefer to use the word "spiritual" rather than "religious." I am not quite as hostile to the idea of religion as Raymond Moody (2012) who stated that "notions of afterlife can exist independent of religion. In fact, I can now say with assurance that 'religion' and 'afterlife' are two entirely different concepts linked together only by religious dogma" (p. 32). Sir Alister Hardy (1997), founder of the Religious Experience Research Centre, asserted that religious experience is not supernatu- 
ral but rather is part of normal reality (pp. 131-142). Some time ago, I began reading scientific literature exploring the ADC phenomenon in which Jesus has appeared to modern people. More importantly, I began paying special attention to the first-hand accounts of people I knew to be credible and not psychotic. When I reexamined the stories of Jesus' resurrection in the New Testament, I was delighted to find that they resembled modern ADCs (Vincent, 2012).

Habermas's (2012) "Response" began with some "forceful reasons" (p. 149) that Jesus' post-resurrection appearances are different from ADCs before he presented his "six major dissimilarities" (p. 153) between Jesus' post-resurrection appearances and contemporary ADCs. I will now try to provide some clarity.

Habermas took issue with my using L. Michael White (2004) for references in dating the gospels. Granted, conservative scholars tend to prefer the earliest dates possible for New Testament writers and liberal scholars generally use later dates, but I did not choose White to "favor my conclusions" (Habermas, 2012, p. 151). I did so for economy; White has used broader time spans, and I find White to be a generally fair source. The 10-year discrepancy in dates is irrelevant to my case; even the earlier date of 60CE is 30 years after Jesus' death and provides plenty of time for myth-making to begin.

Habermas (2012) cited my assertion that Paul's first-hand and second-hand accounts (I Cor 15:4-8) of Jesus being raised in a spiritual body offer more credibility than the later Gospel writers' reports of an empty tomb that implies a bodily resurrection. Sociologist and religious experience researcher James McClenon (2002, p. 116) classified experience as first-hand, second-hand, and folkloric (greater than second-hand). By this standard, most of the Bible is folklore. Many religious experience researchers and liberal Christian scholars (Funk $\&$ the Jesus Seminar, 1998, pp. 449-495) took I Corinthians 15 as the only reliable information about Jesus' resurrection.

In addition, Habermas (2012) took issue with my assertion that Paul's view of a spiritual resurrection is an ADC. He claimed that what I call the "modern view" is actually out-of-date. It is most decidedly not out-of-date with religious experience researchers and liberal Christian scholars such as G. Riley (2001, pp. 154-156), J. Tabor (2006, pp. 230-238, 329-330), W. E. Phipps (2008, pp. 188-210), P. Wiebe (1997, pp. 121-125), J. Hick (2008, pp. 88-95), A. F. Segal (2004, pp. 393, 403-440, 448), J. McClenon (1994, pp. 75-77), J. H. Ellens (2008, p. 159), M. Borg (1997, pp. 92-93), and T. Harpur (2011, pp. 131-156). 
Finally, the Jesus Seminar, a group of liberal scholars intent on separating the authentic words of Jesus from the mythic parts of the Gospels, focused in 1995 on Jesus' resurrection. "More than 90\% of the Fellows and a huge majority of the Associates, agreed that Jesus' resurrection did not involve the resuscitation of a corpse" (Scott, 2008, p. 45, emphasis added) and that his body decayed in the usual way. In my mind, this conclusion puts them in agreement with Paul who clearly stated, "What is sown is perishable, what is raised is imperishable" (I Cor 15:42 NRSV).

Habermas's (2012) point on the translation of John 20:17 is well taken. He stated that new translations have Jesus telling Mary Magdalene not to "hold on" to him rather than to "touch" him. However, this variant in translation does not alter my assertion that the resurrection was a spiritual experience. Modern ADCs sometimes include an aspect of touch between the living and the deceased.

In my view, Habermas (2012) grasped at straws when he cited an obscure point of logic that things can appear similar but not be the same. With this point, he seemed to exclude the possibility that things that appear similar could be the same. In asserting that Jesus' resurrection was unique among all others, Habermas's position flies in the face of the larger truth of Occam's Razor that favors the simplest explanation: Jesus' post-resurrection appearances resemble modern-day ADCs, and so they are. Science is based on observation, and Habermas's argument for exceptionalism in the case of Jesus defies common sense.

Habermas's (2012) survey of scholars who support his view is countered by an exceptionally large number of scholars who favor my position-the largest group being the Jesus Seminar. Their analysis of the true words and deeds of Jesus remains a major piece of scholarship (Funk, Hoover, \& the Jesus Seminar, 1993; Funk \& the Jesus Seminar, 1998). More importantly, new cases of ADCs are continuously being added to databases in departments of social science and medicine in universities and medical schools. Erlendur Haraldsson's (2012) latest book, The Departed Among the Living, is an excellent example that chronicles 449 cases in Iceland.

Habermas began his "Six Major Dissimilarities" with his defense of the empty tomb.

1. Personally, I prefer to leave the question of the empty tomb a mystery, as an empty tomb is simply unnecessary for Jesus' spiritual resurrection (Vincent, 2012). The Jesus Seminar felt that the empty tomb represented a later development (Funk \& the Jesus Seminar, 
1998, p. 462). In "Brand X Easters," Robert Price (2008) noted that the original Gospel of Mark has no resurrection story but ends with the empty tomb. Price also stated that many ancient Hellenistic texts have a missing body and an assurance from a heavenly voice or visitor that the person has been taken to heaven; he asserted that this is enough evidence to indicate an ascension (Scott, 2008, pp 49-53). Price's examples include Herakles, Romulus, and Apollonius of Tyana. Space does not allow me to explore all the possible explanations for the empty tomb, but it is worth noting that James Tabor (2006, pp. 233-240, 319-330) gave several explanations for the empty tomb and proposed his own theory that Jesus was re-buried in a family tomb.

2. Habermas contended that Jesus predicted his own death, unlike cases of modern ADCs. However, the text in Matthew states that at Jesus' death, "the tombs also were opened, and many bodies of the saints who had fallen asleep were raised. After his resurrection they came out of the tombs and entered the holy city and appeared to many" (Matt 27:52-53 NRSV). These were clearly spiritual resurrections, as the bodies of these long-dead saints would have been thoroughly decomposed. Jesus himself anticipated a spiritual resurrection when he proclaimed that at death people become "like angels in heaven" (Matt 22:30, Mk 12:25, Lk 20:36). According to the Jesus Seminar, Jesus' predictions of his own death were put on his lips after the fact (Mk 8:31, 9:31, 10:33-34; Funk et al., 1993, pp. 78, 83, 94). But is the Jesus Seminar correct in this incidence? Mystical experiences of God and psychic ability go hand-in-hand, and Jesus is no exception (Vincent, 2010, p. 12). Premonitions were $7 \%$ of the first 3,000 cases gathered by Sir Alister Hardy, founder of the Religious Experience Research Centre (Hardy, 1997, pp. 26, 45-6). Ordinary people sometimes have premonitions of their own death; Abraham Lincoln is a famous example (Moody, 1994, pp. 3-4). The problem with the New Testament or any other holy book is determining what is factual and what is later myth-making. Modern cases of ordinary people's religious/mystical experiences enhance the credibility of ancient accounts.

3. Habermas said that the ancients were aware that Jesus' resurrection appearances were somehow different from other ADCs. Crossan (1998, pp. xiii-xxxi) refuted this point by arguing that Paul's GrecoRoman audience would have had no problem with Jesus' resurrection because it fit well with their conception of the behavior of gods, heroes, and dead humans.

4. Habermas stated that, according to the New Testament, Jesus made multiple post-resurrection appearances, and that such multi- 
plicity is unlike the ADCs of ordinary individuals. I would add-more profoundly - that modern ADCs with Jesus indicate that Jesus' resurrection is still in progress (Vincent, 2012)! Jesus' mother Mary, who was declared the "Queen of Heaven" by Pope Pius XII (Phipps, 2008, pp. 50-51), is considered by comparative religion scholars to be a goddess in her own right. Apparitions of Mary to multiple witnesses are well-documented, including 14 people at Knock, Ireland in 1879 (Fox, 2008, pp. 39-40); most famously, Mary appeared to 70,000 people who witnessed a unique celestial event at Fatima, Portugal in 1917 (Sparrow, 2002, pp. 125-126). It is worth mentioning that divine beings from other religions such as Lord Krishna (Hick, 2006, p. 34), Amitabha, and Guanyin (Yao \& Badham, 2007, pp. 5, 38), also appear to modern people. In ADCs, ordinary people usually have no need to appear to anyone other than their loved ones. In Hello From Heaven, Bill Guggenheim and Judy Guggenheim (1995) reported instances of ADCs of ordinary people who reappear many years later (p. 256), who sometimes appeared to help loved ones recover lost objects or money (p. 275), who appeared to protect their families from harm (p. 290), who appeared to prevent suicide (p. 307), and who occasionally appear to two or more people (p. 322). Divine Beings have a greater number of people who love them; therefore, they have a greater need to comfort, warn, assure, and save their followers and other souls. The phenomenology of the ADCs is the same for ordinary people and Divine Beings, whether the occurrence is ancient or modern.

5. Habermas returned to the idea that Luke's description of Paul's experience of Jesus in the Acts of the Apostles-written many years later by an author who admitted he was not an eye-witness-is somehow more accurate than Paul's first-hand account. Luke discounted Paul's own account (Phipps, 2008, p. 256; Vincent, 2012). Contrary to Habermas's assertion that light is foreign to ADCs, it occasionally appears in ADC accounts (Fox, 2008, p. 51). More relevant is the fact that Paul himself did not mention light in his own descriptive writing of his religious experience of Jesus (I Cor 15:4-8).

6. Habermas claimed that the majority of modern scholars accept the resurrection of Jesus as a bodily event. This is not remarkable. I am certain that a return to second century Egypt—at a time when the ancient Egyptian religion was being threatened by the spread of various Greco-Roman religions and Christianity—would find a majority of Egyptian priests voting "yes" on the physical resurrection of Osiris and his subsequent elevation to King of the Dead (Mojsov, 2005, pp. $38-53,111-119)$. 
At the beginning of my original paper, I stated that my view of Jesus' resurrection in a spiritual body is favored by liberal theologians and, more importantly, by religious experience researchers. I contended that the differences between Jesus' post-resurrection appearances - as well as Jesus' initial mystical experience of God-and those transpersonal experiences of others are not one of kind but of degree (Vincent, 2010a). In conclusion to this dialog with Habermas, I persist in that contention. Thanks to religious experience research over the past 150 years, including mystical/spiritual experiences, near-death experiences, death-bed visions, and ADCs, humanity currently knows more about how we experience God and afterlife than we have known at any other time in recorded history (Vincent, 2010b, 2011).

\section{References}

Borg, M. (1997). The God we never knew. New York, NY: HarperOne.

Crossan, J. D. (1998). The birth of Christianity. New York, NY: Harper SanFrancisco.

Ellens, J. H. (2008). Understanding religious experiences. London, UK: Praeger.

Fox, M. (2008). Spiritual encounters with unusual light phenomena: Lightforms. Cardiff, Wales: University of Wales Press.

Funk, R., Hoover, R. W., \& the Jesus Seminar. (1993). The five gospels. New York, NY: HarperOne.

Funk, R., \& the Jesus Seminar. (1998). The acts of Jesus: The search for the authentic deeds of Jesus. New York, NY: HarperSanFrancisco.

Guggenheim, B., \& Guggenheim, J. (1995). Hello from heaven. New York, NY: Bantam Books.

Habermas, G. (2012). Resurrection appearances of Jesus as after-death communication: Response to Ken Vincent. Journal of Near-Death Studies, 30(3), 148-157.

Haraldsson, E. (2012). The departed among the living: An investigative study of afterlife encounters. Guildford, UK: White Crow Books.

Hardy, A. (1997). The spiritual nature of man. Oxford, UK: The Religious Experience Research Centre. (original work published 1979)

Harpur, T. (2011). There is life after death. Toronto, Canada: Thomas Allen.

Hick, J. (2006). The new frontier of religion and science: Religious experience, neuroscience, and the transcendent. New York, NY: Palgrave Macmillan.

Hick, J (2008). Who or what is God? London, UK: SCM Press.

James, W. (1990). The varieties of religious experience. New York, NY: Literary Classics of the United States. (original work published 1902)

McClenon, J. (1994). Wondrous events: Foundations of religious beliefs. Philadelphia, PA: University of Pennsylvania Press.

McClenon, J. (2002). Wondrous healing: Shamanism, human evolution, and the origin of religion. DeKalb, IL: Northern Illinois University Press.

Mojsov, B. (2005). Osiris: Death and afterlife of a god. Malden, MA: Blackwell. 
Moody, R. (1994) Reunions: visionary encounters with deceased loved ones. New York, NY: Ivy Books.

Moody, R. (2012). Paranormal: My life in pursuit of the afterlife. New York, NY: HarperOne.

Phipps, W. E. (2008). Supernaturalism in Christianity: Its growth and cure. Macon, GA: Mercer University Press.

Price, R. M. (2008). Brand X Easters. In B. B. Scott (Ed.), The resurrection of Jesus: A sourcebook (pp. 49-60). Santa Rosa, CA: Polebridge Press.

Riley, G. J. (2001). The river of God: A new history of Christian origins. New York, NY: HarperSanFrancisco.

Scott, B. B. (Ed.). (2008). The resurrection of Jesus: A sourcebook. Santa Rosa, CA: Polebridge Press.

Segal, A. F. (2004). Life after death: A history of the afterlife in the religions of the West. New York, NY: Doubleday.

Sparrow, G. S. (2002). Sacred encounters with Mary. Notre Dame, IN: Ave Maria Press.

Tabor, J.D. (2006). The Jesus dynasty with a new epilogue. New York, NY: Simon \& Schuster.

Vincent, K. R. (2007). Separating the 'super' from the 'natural.' De Numine, 42, $5-8$.

Vincent, K. R. (2010a). Religious experience, Jesus, and modern research an appraisal of the Jesus Seminar findings. De Numine, 49, 10-12.

Vincent, K. R. (2010b). The search for God and afterlife in the age of science. Journal of Near-Death Studies, 28(3), 123-141.

Vincent, K. R. (2011). What the near-death experience and other spiritually transformative experiences teach us about God and afterlife. De Numine, 51, 9-13.

Vincent, K. R. (2012). Resurrection appearances of Jesus as after-death communication. Journal of Near-Death Studies, 31, 30(3), 136-147.

White, L. M. (2004). From Jesus to Christianity. New York, NY: HarperSan Francisco.

Wiebe, P. H. (1997). Visions of Jesus: Direct encounters from the New Testament to today. New York, NY: Oxford University Press.

Yao, X., \& Badham, P. (2007). Religious experience in contemporary China. Cardiff, Wales: University of Wales Press. 